\title{
Impact of Culture Filtrate of Piriformospora indica on Biomass and Biosynthesis of Active Ingredient Aristolochic Acid in Aristolochia elegans Mart
}

\author{
Uttamkumar S. Bagde ${ }^{1,2}$, Ram Prasad ${ }^{2} \&$ Ajit Varma ${ }^{2}$ \\ ${ }^{1}$ Applied Microbiology Laboratory, Department of Life Sciences, University of Mumbai, India \\ ${ }^{2}$ Amity Institute of Microbial Technology, Amity University-Uttar Pradesh, India \\ Correspondence: Uttamkumar S. Bagde, Department of Botany, School of Biological Sciences, Dr. Harising \\ Gour Central University, Sagar-470003 (Madhya Pradesh) India. E-mail: bagdeu@yahoo.com; \\ usbagde@gmail.com
}

\author{
Received: January 4, 2013 Accepted: September 4, 2013 Online Published: November 11, 2013 \\ doi:10.5539/ijb.v6n1p29 URL: http://dx.doi.org/10.5539/ijb.v6n1p29
}

\begin{abstract}
The mycorrhiza plant partnership is the basic, essential and integral part of plant survival and growth. In the present investigation we are reporting the effect of culture filtrate of Piriformospora indica, a growth promoter and bioprotector fungus on Aristolochia elegans Mart. The culture filtrate of the fungus increased overall growth, biomass, and active ingredient-aristolochic acid in the leaves of plants. In untreated control plants, the overall growth was reduced. $P$. indica culture filtrate application increased root number, root length, and root dry weightby $28 \%, 98 \%$, and $123 \%$ respectivelyin plants of Aristolochia. Also stem height and shoot length was enhanced by $43 \%$ and $155 \%$ respectively. There was increase in number of leaves by $79 \%$ and length of leaves by $36 \%$. The increase in total biomass was $136 \%$. The improvement in content of aristolochic acid in leaves was between $7.6 \%$ and $28.8 \%$ in treated plants as against untreated control plants
\end{abstract}

Keywords: Aristolochia elegans, aristolochic acid, Piriformospora indica, symbiotic fungus

\section{Introduction}

The fungus Piriformospora indica, is related to the Hymenomycetes of the Basidiomycota, which is a root endophyte that has capabilities of a typical, arbuscular mycorrhizal fungus, (Verma et al., 1998; Weiss et al., 2004; Prasad et al., 2008a; Bagde et al., 2010a, 2010b, 2010c, 2011), but unlike Arbuscular Mycorrhizal fungi it is cultivable in axenic conditionseasily. This mycorrhiza like fungus can form association with roots for enhanced growth and development of plants (Varma et al., 1999, 2001; Oelmüller et al., 2009; Sirrenberg et al., 2007; Prasad et al., 2008a; Bagde et al., 2011). P. indica interacted mutually with various plants including Fabaceae and Rhamnaceae species (Varma et al., 2001), Arabidopsis (Peškan-Berghöfer et al., 2004), tobacco (Barazani et al., 2005), Poaceae species (Waller et al., 2005).

$P$. indica enhanced nutrient uptake, helped plants to survive in extreme drought,temperature and salt conditions, exhibited systemic resistance to toxins, acted as biofertilizer, bioprotector, stimulator of growth, increased seed production, and played a key role in increasing the tolerance to insects (Varma et al., 1999; Waller et al., 2005, 2007; Serfling et al., 2007; Prasad et al., 2008a, 2008b). It helps in biological hardening to tissue culture raised plants, provides protection against 'shock of transplantation 'and pathogens of roots (Sahay \& Varma, 1999; Hazarika, 2003; Prasad et al., 2008a, 2008b).

Aristolochia elegans plant belongs to Aristolochiaceae family. It is generally called pine vines or Dutchman's pipes. It is an annual plant with slender, woody stems, climber on support with heart shaped leaves and calico flower. It grows all over the world including in tropical climates such as India and other countries and is also called birthworts and commonly used to ease pain of childbirth, treat malaria and other diseases (Kimura \& Kimura, 1981). Plant is cultivated and used in some medicinal preparations in China (Lopes et al., 2001). It contains important alkaloid aristolochic acid which is antimicrobial in nature (Imran \& Bagde, 2007) and is useful for variety of ailments. The fruits and roots have been used by Chinese people in medicine as anodynes, antiphlogistics, expectorants and anti-asthmatic agents and is also used in treatment of snakebite, anti-tumor, anti-platelet aggregator agent and lung inflammation (Vila et al., 1997; Wu et al., 1999; Tian-Shung et al., 2000). 
However, its certain harmful activities such as mutagenicity and carcinogenicity have also been reported (Arlt et al., 2002).

So far all the accounts are on the interaction of fungus propgules but in this communication we document that $P$. indica culture filtrate also enhanced the overall growth parameters of Aristolochia elegans and contents of aristolochic acid in leaves.

\section{Materials and Methods}

\subsection{Mycobiont}

P. indica culture for this study was procured from Amity University'sAmity Institute of Microbial Technology, India.

\subsection{Photosymbiont}

Aristolochia elegans Mart. (Aristolochiaceae) is the perennial shrub cultivated as ornamental plant in India. Species of Aristolochia are cultivated and used in medicinal preparations (Lopes et al., 2001). The plantlets were procured from Jijamata Udyan Byculla, Mumbai, India and were multiplied in environmentally controlled green house. Sterile substratum was used to conduct the experiments.

\subsubsection{Culturing the Fungus $P$. indica}

A. elegans was cultivated and maintained on modified synthetic media fortified with $1.2 \%$ agar $(\mathrm{w} / \mathrm{v})$ in dark at $28 \pm 2{ }^{\circ} \mathrm{C}$ (Hill \& Käfer, 2001; Prasad et al., 2005). pH of medium was kept at 6.5. For mass propagation, the fungus was also cultivated in liquid broth medium under constant shaking at $120 \mathrm{rpm}$ in dark (GFL 3019, Germany). Media were sterilized in autoclave at 15 psi pressure for 15 minutes.

\subsubsection{Separation of Culture Filtrate}

The fungus was grown in liquid medium for 15 days and was first filtered through sterile muslin cloth followed by bacterial filter (Millex-GV, $0.22 \mu \mathrm{m}$ Filter Unit, Millipore) and kept at $4{ }^{\circ} \mathrm{C}$ if not used afresh.

\subsubsection{Co-Cultivation Experiments}

Plantlets grown for Fifteen days were transferred to sterile $10^{\prime \prime}$ diameter plastic pots containing sterile unfertilized garden soil autoclaved on three consecutive days. Initially two plantlets were planted in each pot. Once they got acclimatized then one of the plantlet was removed, finally retaining only one plantlet in each pot. To each pot containing $1 \mathrm{~kg}$ of soil $15 \mathrm{ml}$ of freshly eluted culture filtrate to experimental pots and an equal volume of sterile nutrient medium were added to control pots one day before transfer of the plantlet into the pots. Again after a period of one month this treatment was repeated.

\subsubsection{Growth Conditions}

Pots were kept in green house at temperature of $26 \pm 2{ }^{\circ} \mathrm{C}$ and $16 \mathrm{~h} \mathrm{light} / 8 \mathrm{~h}$ dark and $60 \%-70 \%$ relative humidity and a light intensity of 20,000 lux. Growth of plants was measured after 90 days by use of centimeter scale. For estimation of dry biomass, plant was chopped and dried at $80^{\circ} \mathrm{C}$ for $12 \mathrm{~h}$ in a Memmert oven and dry biomass was estimated after cooling at room temperature and weighing on electric- mono-pan balance.

\subsection{Aristolochic Acid Analysis}

Leaves of Aristolochia were used to extract and estimate aristolochic acid. For preparation of extract, leaf material was ground to fine powder by mechanical grinding using HPLC grade methanol and formic acid. $2 \mathrm{gm}$. of ground sample was taken in a bottle, thoroughly mixed with a mixture of $50 \mathrm{ml}$ of methanol $(80 \%)$ and $20 \mathrm{ml}$ of 10\% formic acid in water. The contents were stirred for 30 minutes at $500 \mathrm{rpm}$ (Innova Model 2001 bench top platform shaker, New Brunswick, USA) and then centrifuged for 4 minutes at $4000 \mathrm{rpm}$. The supernatant was taken for determination of aristolochic acid (Gaudreault et al., 2001; Flurer et al., 2001). Estimation of aristolochic acid in the leaves extract of $A$. elegans was carried out by HPTLC using standard aristolochic acid as reference (Sigma, USA) in the range of 0-200 $\mu \mathrm{g} / \mathrm{ml}$. Stationary phase used for HPTLC contained Silica gel 60 (Merck) plates of 10x10 cm size. The mobile phase used for the chromatogram consisted of toluene, ethyl acetate, water and formic acid in the ratio of 20:10:1:1. The sample used was $10 \mu \mathrm{g}$. For developing the plate twin trough chamber was saturated for 20 minutes and the plate was dried with hair drier (cold air) for 5 minutes. The plate was evenly sprayed with tin (II) chloride reagent and further dried at $100{ }^{\circ} \mathrm{C}$ for a minute. Plates were observed under UV light at $366 \mathrm{~nm}$ and acid content was measured. This was determinedafter 15, 30, 45, 60, 75 and 90 days. 


\section{Results and Discussion}

When morphological appearance of $P$. indica was observed on Käfer agar medium the pattern of growth of the fungus was marked by uniform rhythmic zonation (Figure 1a). The rapid growth on Käfer nutrient broth was observed after 15 days incubation at temperature of $28 \pm 2{ }^{\circ} \mathrm{C}$ (Figure 1b). The colonies showed prominent crowded balls of coral morphology in conformity with previous studies by various workers (Varma et al., 2001; Singh et al., 2003). The important characteristics of this organism have been described earlier (Varma et al., 2001).

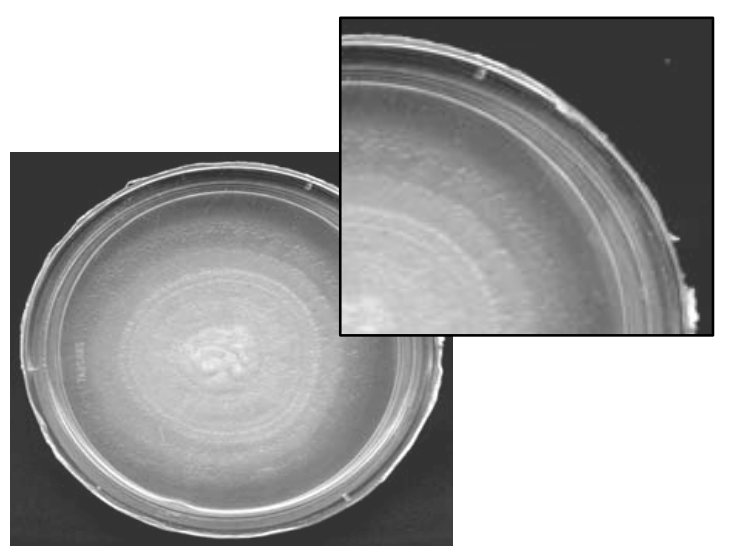

Figure 1(a). Growth of $P$. indica on solidified agar medium

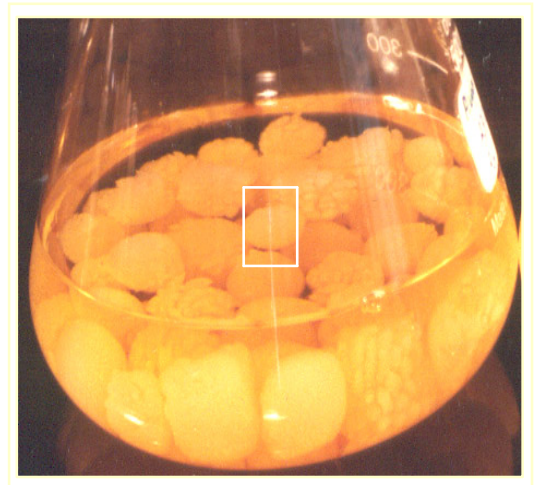

Figure 1(b). Cultivation of $P$. indica in aspergillus broth medium

The observations made in this study indicated that culture filtrate of fungus exerted positive impact on various parameters of the plant as depicted in Figures $2 \& 3$ and Tables $1 \& 2$. When A. elegans plant was treated with culture filtrate $P$. indica, it enhanced the number, length and biomass of the root (Table 1). Pretreatment also resulted in an increase in root number, root length and root dry weight by $28 \%, 98 \%$, and $123 \%$ respectively in Aristolochia. Increased root length and number can enhance absorption of more nutrients due to increased absorbing area resulting in improved plant growth (Marschner \& Dell, 1994). Similar observations were made by other workers (Mugnier \& Mosse, 1987; Varma et al., 2001). Inoculation of culture filtrate in case of grasses, trees and herbaceous sp. also showed enhancement of plant growth (Varma et al., 2001). 


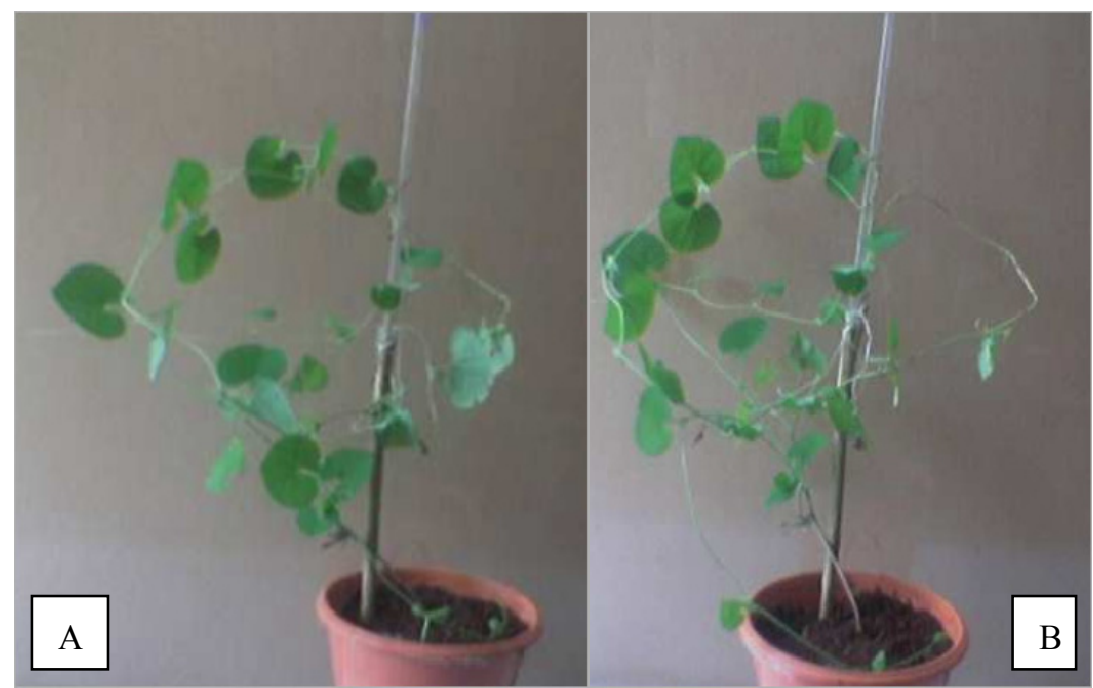

Figure 2. Effects of P. indica culture filtrate inoculation on Aristolochia elegans(A treated and B untreated)
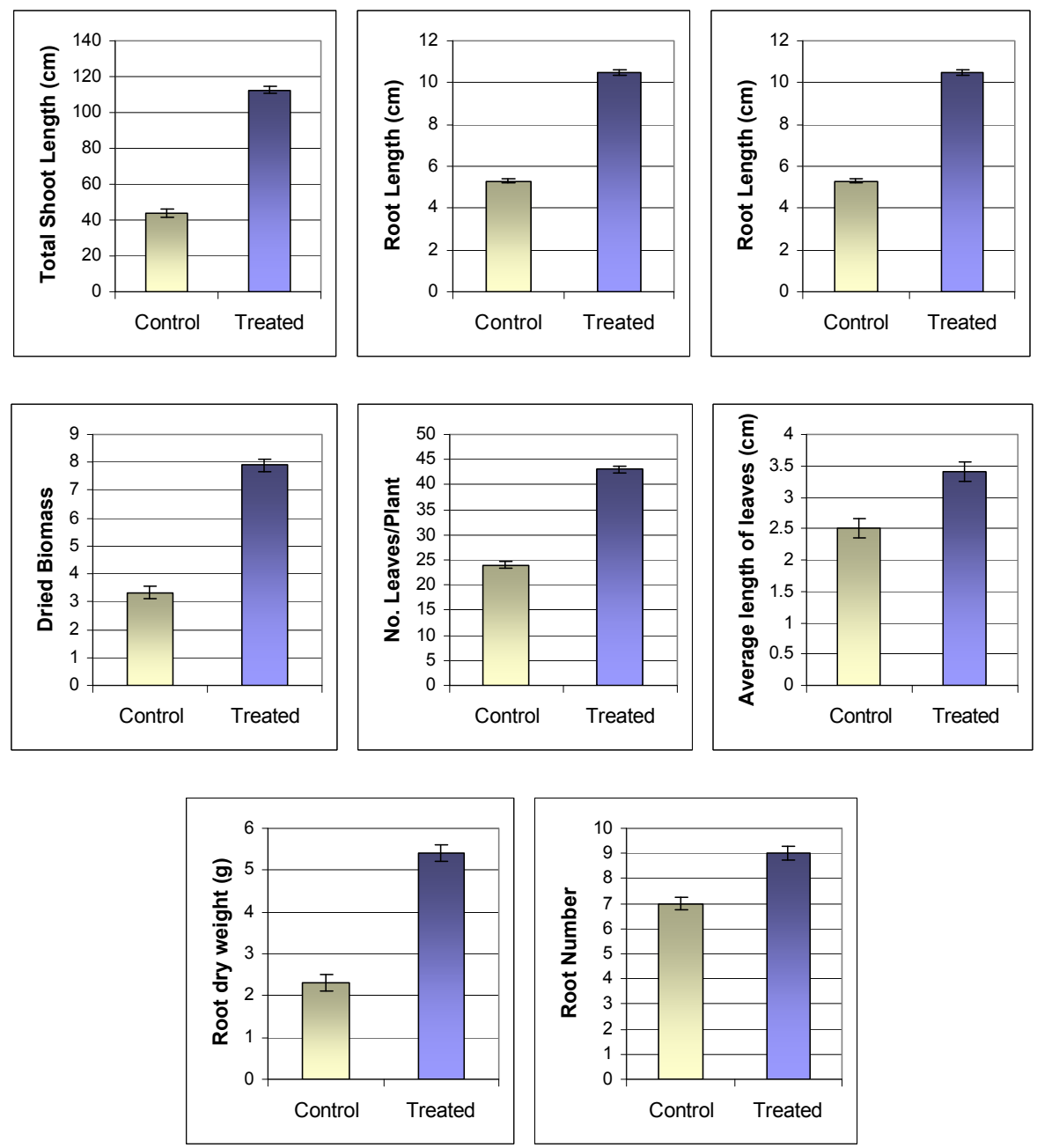

Figure 3. Effect of P. indica culture filtrate on Aristolochia elegans 


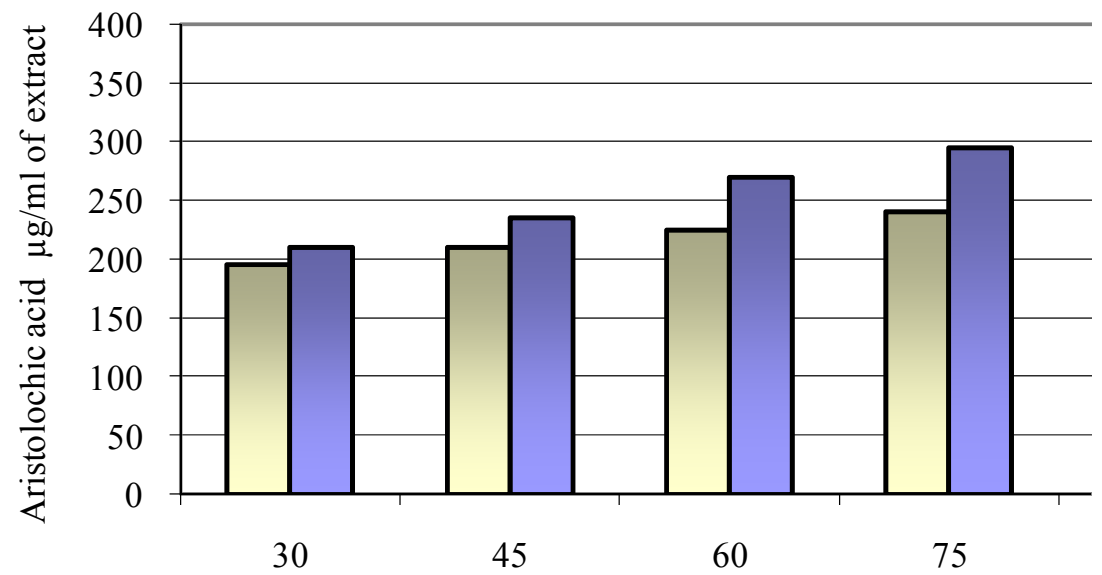

Figure 4. Effects of P. indica inoculation on Concentrations of Aristolochic acid in leaves of Aristolochia elegans

Table 1. Effect of P. indica culture filtrate on growth performance of Aristolochia elegans. Average values are for five replicates

\begin{tabular}{llccccc}
\hline & Characteristics & $\begin{array}{c}\text { Control } \\
\text { (untreated) }\end{array}$ & $\begin{array}{c}\text { Experimental } \\
(P . \text { indica } \text { treated) }\end{array}$ & S. E. & S. D. & $\begin{array}{c}\text { Percent increase } \\
\text { over control }\end{array}$ \\
\hline Root & Number & 7.00 & 9.00 & \pm 0.26 & 0.2 & 28 \\
& Length(cm) & 5.30 & 10.5 & \pm 0.12 & 0.12 & 98 \\
& Dry weight (g) & 2.30 & 5.4 & \pm 0.20 & 0.20 & 123 \\
\multirow{5}{*}{ Stem } & Height(cm) & 7.20 & 10.5 & \pm 0.02 & 0.02 & 43 \\
& Shoot & 44.00 & 112.5 & \pm 2.17 & 2.17 & 155 \\
& length(cm) & & & & & \\
Leaves & Number & 24.00 & 43.0 & \pm 0.68 & 0.68 & 79 \\
& Length(cm) & 2.50 & 3.4 & \pm 0.15 & 0.15 & 36 \\
Total & Roots, Stems, & 3.32 & 7.9 & \pm 0.22 & 0.22 & 136 \\
Biomass (g) & Leaves, & & & & & \\
\hline
\end{tabular}

S. E $=$ Standard Error; S. D. = Standard Deviation.

Table 2. Effects of $P$. indica inoculation on Concentrations of Aristolochic acid in leaves of Aristolochia elegans

\begin{tabular}{ccccc}
\hline \multirow{2}{*}{ Days After planting } & \multicolumn{2}{c}{ Aristolochic acid $\mu \mathrm{g} / \mathrm{g}$ of extract } & & \\
\cline { 2 - 3 } & $\begin{array}{c}\text { Un-treated } \\
\text { (Control) }\end{array}$ & Treatment with P. indica & S. D. & $\begin{array}{c}\text { Percent increase over the } \\
\text { Control }\end{array}$ \\
\hline 30 & $195 \pm 1.76$ & $210 \pm 1.76$ & 1.76 & 7.6 \\
45 & $210 \pm 2.10$ & $235 \pm 2.10$ & 2.10 & 11.9 \\
60 & $225 \pm 5.64$ & $270 \pm 5.64$ & 5.64 & 20.0 \\
75 & $240 \pm 4.85$ & $295 \pm 4.85$ & 4.85 & 22.8 \\
90 & $260 \pm 6.47$ & $335 \pm 6.47$ & 6.47 & 28.8 \\
\hline
\end{tabular}

Enhanced root growth, and root length was observed after application of the fungus in several plant species studied earlier (Varma et al., 2001). Not only the mycelium but even culture filtrate enhanced growth of the plants. Earlier it was reported that plant root cells can be killed by colonization of this fungus (Deshmukh et al., 2006), however it also increased root growth, weight and branching (Varma et al., 1999; Waller et al., 2005). 
Increased rooting of calli of $N$. tabacum and cuttings of other plants was also noticed (Varma et al., 1999; Drudge et al., 2007). When culture filtrate of $P$. indica was applied, a diffusible factor from it enhanced root growth of Arabidopsis. There was stunted but highly branched roots in treated plants (Sirrenberg, 2007). The overall increment in the plant growth reported in this study may be due to increased nutrients uptake by the roots. This may also be due to application of culture filtrate that contained many growth promoters that exerted desirable effect on plant.

When culture filtrate of $P$. indica was applied, Increments in stem height and shoot length of plants were observed in plants in the present study (Table 1). Stem height increased by $43 \%$ and shoot length by $155 \%$. This is in conformity to observations made in earlier investigations (Varma et al., 2001; Nautiyal et al., 2010; Bagde et al., 2010a, 2011).

The number of leaves increased by $79 \%$ and length by $36 \%$ in $P$. indica culture filtrate treated plants in comparison to untreated plants (Table 1) Increase in number and length of leaves was also reported in other plants using fungal mass or fungal culture filtrate (Varma et al., 2001; Fakhro et al., 2010; Bagde et al., 2011). A greater number of leaves, with increased length produced in treated plants could have contributed to increased rate of photosynthesis (Kungu, 2004).

P. indica culture filtrate treatment enhanced growth as well as total biomass of plants in comparison to untreated control plants in present study (Table 1). Similarly there was reported increase in total biomass by $136 \%$ as against treated control plants in herbaceous species (Varma et al., 2001) and Helianthus annus (Bagde et al., 2011), winter wheat plants (Serfling et al., 2007).

When six strains of Sebacina vermifera were tested on Panicum virgatum roots, it was noticed that there was positive effects on plant height and biomass production. It was also observed that culture filtrates from some strains of $S$. vermifera increased seed germination in $P$. virgatum by $52 \%$ over the control. In spring barley $P$. indica increased plant biomass and grain yield by $11 \%$ (Waller et al., 2005). Serfling et al. (2007) observed that fungus $P$. Indica colonization increased plant biomass in winter wheat plant.

When fungal culture filtrate was applied to the soil before planting, it increased total content of aristolochic acid in leaves between $7.6 \%$ to $28.8 \%$ (Table 2). The quantity of leaves and content therein were augmented as compared to control plants when treated plantlets were transferred to the pots. This positive influence in promoting the plant growth and yield in terms of biomass and medicinal ingredients may be due to positive effect of stimulatory factors or components present in the culture filtrate.

Besides several reports pertaining to the association of cells of $P$. indica with plants that enhanced growth, present study reports positive effect of even culture filtrate of fungus on plant growth. This is due to special characteristics of culture filtrate that was used. Culture filtrate is a complex growth enhancer of which all ingredients are not known (Bagde et al., 2010b). Culture filtrate contains fungal exudates, hormones, enzymes, proteins etc. that increased root number, length, root dry weight, stem height, shoot length, number and length of leaves, total biomass and aristolochic acid content of leaves in culture filtrate treated plants. Similar observations were made in case of maize, Bacopa monniera, and tobacco (Varma et al., 2001), neem and maize (Kumari, 2002; Singh et al., 2003). In Helianthus annus, treatment with $P$. indica culture filtrate promoted overall growth of the plant in terms of increased, root collar diameter, number of secondary roots, root length, root weight, stem diameter, stem height, number of leaves, length and width of leaf, flower number, flower diameter, flower dry weight, number of seeds, weight of seeds and total biomass as compared to untreated control plants. Seed oil content considerably increased in treated plants. Seed oil content increased by 51.13 per cent in sun gold variety and 70.33 per cent in treated Japanese gold variety of H. annus plants (Bagde et al., 2011).

Varma et al. (2001) also reported that application of culture filtrate of $P$. indica led to increase in root length, shoot length and plant biomass in treated plants. In present study treatment of Aristolochia elegans increased growth of roots, stems, leaves, total biomass as well as aristolochic acid over untreated plants (Table 1). These observations are in conformity to observations of Singh et al. (2003) wherein treatment resulted in considerable increase in growth and development in Azadiracta indica and Zea mays plants. Similarly when Helianthus annus plants were treated with culture filtrate of $P$. indica, root number, length, root collar diameter and dry weight of root increased considerably (Bagde et al., 2011). Observations like these were also made by other investigators, who reported luxurious and elaborate root growth and biomass when treated with mycelia of fungus (Varma et al., 2001; Kungu, 2004).

According to Sirrenberg et al. (2007) actual mode of action of $P$. indica in enhancing the growth of plants was not yet clear. But it is suggested that effect was due to diffusible factor that could be IAA, as P. indica was found to produce IAA in culture filtrate in sufficient quantities and hence it must have contributed to the beneficial 
effect on its host plants. The fungus may in addition induce auxin production in the plant (Peškan-Berghöfer et al., 2004). Plants colonized with $P$. indica can tolerate physical stress, nutrient deficiency, biotic and abiotic stresses and can fight pathogens including invaders of insects and facilitated increase in seeds and early flowering in medicinal plants (Oelmüller et al., 2009).

\section{References}

Arlt, V. M., Stiborova, M., \& Schmeiser, H. H. (2002). Aristolochic acid as a probable human cancer hazard in herbal remedies: A review. Mutagenesis, 17(4), 265-27. http://dx.doi.org/10.1093/mutage/17.4.265

Bagde, U. S. (2010a). Impact of Bio inoculants on economically important plants: Development and formulations. D. Sc. thesis submitted to Amity University Uttar Pradesh, India.

Bagde, U. S., Prasad, R., \& Varma, A. K. (2010b). Characterization of culture filtrates of Piriformospora indica. Asian J. Microbiol Biotech. Env. Sc., 12, 805-809.

Bagde, U. S., Prasad, R., \&Varma, A. K. (2010c). Interaction of $P$. indica with medicinal plants and plants of economic importance. African Journal of Biotechnology, 9(54), 9214-9226.

Bagde, U. S., Prasad, R., \& Varma, A. K. (2011). Influence of culture filtrate of Piriformospora indica on growth and yield of seed oil in Helianthus annus. Symbiosis (USA), 53, 83-88. http://dx.doi.org/10.1007/s13199-011-0114-6

Barazani, O., Benderoth, M., Groten, K., Kuhlemeier, C., \& Baldwin, I. T. (2005). Piriformospora indica and Sebacina vermifera increase growth performance at the expense of herbivore resistance in Nicotiana attenuata. Oecologia, 146, 234-243. http://dx.doi.org/10.1007/s00442-005-0193-2

Deshmukh, S., Hückelhoven, R., Schäfer, P, \& Imani, J. (2006). The root endophytic fungus Piriformospora indica requires host cell death for proliferation during mutualistic symbiosis with barley. Proc. Natl. Acad. Sci. USA, 103, 18450-18457. http://dx.doi.org/10.1073/pnas.0605697103

Drudge, U., Baltruschat, H., \& Franken, P. (2007). Piriformospora indica promotes adventitious root formation in cuttings. Science and Horticulture, 112, 422-426. http://dx.doi.org/10.1016/j.scienta.2007.01.018

Fakhro, A., Andrade-Linares, R. D., Bargen, S., \& Bandte, M. (2010). Impact of Piriformospora indica on tomato growth and on interaction with fungal and viral pathogens. Mycorrhiza, 20, 191-200. http://dx.doi.org/10.1007/s00572-009-0279-5

Flurer, R. A., Jones, M. B., Vela, N., Ciolino, L. A., \& Wolnik, K. A. (2001). Determination of aristolochic acid in traditional Chinese medicines and dietary supplements. FDA Laboratory Information Bulletin 4212, 16(7), 13 .

Gaudereault, F., Richad, B., \& Jean, F. P. (2001). Determination of aristolochic acid in natural health products. Health Canada, 10-12.

Ghimire, S. R., Charlton, N. D., \& Craven, K. D. (2009). The mycorrhizal fungus, Sebacina vermifera, enhances seed germination and biomass production in switch grass (Panicum virgatum L). BioEnergy Research 2, 51-58. http://dx.doi.org/10.1007/s12155-009-9033-2

Hazarika, B. N. (2003). Acclimatization of tissue-cultured plants. Current Science, 85, 1704-1712.

Hill, T. W., \& Käfer, E. (2001). Improved protocols for Aspergillus medium: trace elements and minimum medium salt stock solutions. Fungal Genetics Newsletter, 48, 20-21.

Imran, M. S., \& Bagde, U. S. (2007). Screening of Aristolochia elegansfor antibacterial activity. Natl. J. of Life Sciences, 4(2), 219-222.

Kimura, K., \& Kimura, T. (1981). Medicinal Plants of Japan in Color (p. 63). Tokyo: Koikushe Publishing Co..

Kumari, M. (2002). Mycorrhizae for better establishment of neem plantlets (biological hardening) and enhancement of therapeutic properties. Thesis submitted to B. R. Ambedkar Bihar University, Muzaffarpur for the award of the degree of Doctor of Philosophy in Botany.

Kungu, J. B. (2004). Effect of Vesicular Arbuscular Mycorrhiza (V. A. M.) inoculation on growth performance of Senna spectabilis. In A. Bationo (Ed.), Managing nutrient cycles to sustain soil fertility in sub Saharan Africa (pp. 433-446). Nairobi, Kenya: Academy Science Publishers.

Lopes, X., Nascimento, I. R., Silva, T., \& Da, L. M. (2001). Phytochemistry of the aristolochiaceae family. In R. M. M. Mohan (Ed.), Research Advances in Phytochemistry (Vol. 2, pp. 19-108). Global Research Network Kerala. 
Marschner, H., \& Dell, B. (1994). Nutrient uptake in mycorrhizal symbiosis. Plant and Soil, 159, 89-102.

Mugnier, J. \& Mosse, B. (1987). V. A. M. infection in transformed root inducing T-DNA root grown axenically. Phytopathology, 77, 1045-1050. http://dx.doi.org/10.1094/Phyto-77-1045

Nautiyal, C. S., Chauhan, P. S., Mehta, D. S., Seem, K., Varma A., \& Staddon, W. J. (2010). Tripartite interactions among Paenibacillus lentimorbus NRRL B-30488, Piriformospora indica DSM 11827, and Cicer arietinum L. World Journal of Microbiology and Biotechnology, 26, 1393-1399. http://dx.doi.org/10.1007/s11274-010-0312-z

Oelmüller, R., Sherameti, I., Tripathi, S., \& Varma, A. (2009). Piriformospora indica, a cultivable root endophyte with multiple biotechnological applications. Symbiosis, 49, 1-18. http://dx.doi.org/10.1007/s13199-009-0009-y

Peškan-Berghöfer, T., Shahollari, B., Pham, H. G., Hehl, S., Markent, C., Blank, V., ... Oelmüller R. (2004). Association of Piriformospora indica with Arabidopsis thaliana roots represent a novel system to study beneficial plant-microbe interactions and involve in early plant protein modifications in the endocytoplasmic reticulum and in the plasma membrane. Plant Physiology, 122, 465-471. http://dx.doi.org/10.1111/j.1399-3054.2004.00424.x

Prasad, R., Bagde, U. S., Pushpangadan, P., \& Varma, A. (2008a). Bacopa monniera L: Pharmacological aspects and case study involving Piriformospora indica. International Journal of Integrative Biology, Singapore, 3, $100-110$.

Prasad, R., Sharma, M., Chatterjee, S., Chauhan, G., Tripathi, S., Das, K. S., ... Varma, A. (2008b). Interactions of Piriformospora indica with medicinal plants. In A. Varma, \& B. Hock (Eds.), Mycorrhizae 3rd Edition (pp. 655-678). Germany: Springer-Verlag.

Rai, M. K., Varma, A., \& Pandey, A. K. (2004). Enhancement of antimycotic potential in Spilanthes calva after inoculation of Piriformospora indica, a new growth promoter. Mycoses, Germany, 47, 479-481. http://dx.doi.org/10.1111/j.1439-0507.2004.01045.x

Sahay, N. S., \& Varma, A. (1999). Piriformospora indica: a new biological hardening tool for micropropagated plants. FEMS Microbiology Letters, 181, 297-302. http://dx.doi.org/10.1111/j.1574-6968.1999.tb08858.x

Serfling, A., Wirsel, S. G. R., Lind, V., \& Deising, H. B. (2007). Performance of the biocontrol fungus Piriformospora indica on wheat under greenhouse and field conditions. Phytopathology, 97, 523-531. http://dx.doi.org/10.1094/PHYTO-97-4-0523

Singh, A. N., Singh, A. R., Kumari, M., Rai, M. K., \& Varma, A. (2003). Biotechnological importance of Piriformospora indica. A novel symbiotic mycorrhiza-like fungus: An Overview. Indian Journal of Biotechnology, 2, 65-75.

Sirrenberg, A., Göbel, C., Grond, S., Czempinski, N., Ratzinger, A., Karlovsky, P., Santos, P., ... Pawlowski, K. (2007). Piriformospora indica affects plant growth by auxin production. Physiologia Plantarum, 131, 581-589. http://dx.doi.org/10.1111/j.1399-3054.2007.00983.x

Tian-Shung, W., Yu-Yi, C, \& Yann-Li. (2000). The constituents of the root and stem of Aristolochiacucurbitifolia Hayata and their biological activity. Chem Pharm Bull, 48, 1006-1009. http://dx.doi.org/10.1248/cpb.48.1006

Varma, A., Singh, A., Sudha, S. N., Sharma, J., Roy, A., Kumari, ... Kranner, I. (2001). Piriformospora indica: A cultivable mycorrhiza-like endosymbiotic fungus. In K. Esser, \& P. A, Lemke (Eds.), Mycota IX (pp. 123-150). Germany: Springer-Verlag.

Varma, A., Verma, S., Sudha, S. N., Britta, B., \& Franken, P. (1999). Piriformospora indica-a cultivable plant growth promoting root endophyte with similarities to arbuscular mycorrhizal fungi. Applied and Environmental Microbiology, 65, 2741-2744.

Verma, S., Varma, A., Rexer, K. H., Hassel, A., Kost, G., Sarbhoy, A., ... Franken, P. (1998). Piriformospora indica gen. nov., a new root-colonizing fungus. Mycologia (USA), 90, 896-909. http://dx.doi.org/10.2307/3761331

Vila, R., Mundina, M., Muschietti, L., Priestap, H., Bandoni, A. L., Priestap, H., ... Bahigueral, S. (1997). Volatile constituents of leaves, roots and stems from Aristolochia elegans. Phytochemistry, 46(6), 1127-1129. http://dx.doi.org/10.1016/S0031-9422(97)00400-7

Waller, F., Achatz, B., \& Kogel, K. H. (2007). Analysis of plant protective potential of the root endophytic 
fungus Piriformospora indica in cereals. In A. Varma, \& R. Oelmüller (Eds.), Advanced Techniques in Soil Microbiology (pp. 343-354). Heidelberg, Berlin: Springer. http://dx.doi.org/10.1007/978-3-540-70865-0_22

Waller, F., Baltruschat, H., Achatz, B., Becker, K., Fischer, M., Fodor, J., ... Kogel, K. H. (2005). The endophytic fungus Piriformospora indica reprograms barley to salt stress tolerance, disease resistance and higher yield. Proceedings of the National Academy of Sciences (USA), 102, 13386-13391. http://dx.doi.org/10.1073/pnas.0504423102

Weiss, M., Selosse, M. A., Rexer, K. H., Urban, A., \& Ober W. F. (2004). Sebacinales: a hitherto overlooked cosm of heterobasidiomycetes with a broad mycorrhizal potential. Mycological Research, 108, 1003-1010. http://dx.doi.org/10.1017/S0953756204000772

Wu, T., Chan, Y., Leu, Y., Wu, P., Li, C., \& Mori, Y. (1999). Four Aristolochic acid esters of rearranged ent. Elemone Sesquiterpenes from Aristolochia heterophylla. J. Nat. Prod., 62, 348-351. http://dx.doi.org/10.1021/np980212y

\section{Copyrights}

Copyright for this article is retained by the author(s), with first publication rights granted to the journal.

This is an open-access article distributed under the terms and conditions of the Creative Commons Attribution license (http://creativecommons.org/licenses/by/3.0/). 